Audrey Kurth Cronin

\title{
EXAMINING DERADICALIZATION PROGRAMS
}

DOI: $10.20542 / 2307-1494-2017-1-106-115$

Keywords: radicalization, deradicalization, disengagement, terrorism, radical Islamism, rightwing extremism, left-wing extremism, ethno-nationalist extremism, counterterrorism, countering violent extremism, United States, Russia, Germany, Norway, Saudi Arabia, effectiveness of deradicalization programs

\begin{abstract}
The article sets the context for addressing radicalization and potential for deradicalization in the United States and Russia, as well as more generally. It briefly explores the debates on what is radicalization and what moves radicalized people and groups to violence. It also introduces the concept of deradicalization and shows the benefits and positive results of deradicalization programs, as well as their drawbacks and the problems with assessing their effectiveness. In conclusion, the author argues that, while deradicalization programs must be carefully tailored for specific contexts that vary from state to state and even person-to-person, they must also be supported by internationally linked research and cooperation.
\end{abstract}

Ключевые радикализация, дерадикализация, терроризм, радикальный исламизм, слова:

правый экстремизм, левый экстремизм, радикальный этнонационализм, противодействие терроризму, противодействие насильственному экстремизму, США, Россия, ФРГ, Норвегий, Саудовская Аравия, эфрфективность программ дерадикализации

Аннотация: Статья исследует почву для анализа проблем радикализации и усилий по дерадикализации в США и России, а также в более широком контексте. В ней сделан краткий обзор дискуссий по вопросам о том, что такое радикализация и какие фракторы и условия способствуют переходу радикализированных лиц и групп к насилию. В статье также представлена концепция дерадикализации и приведены как преимущества и позитивные примеры программ по дераликализации, так и их недостатки и проблемы в оценке их эффрективности. В заключении автор делает вывод о том, что, хотя программы по дерадикализации должны быть максимально адаптированы к конкретным контекстным условиям, варьирующимся от одного государства к другому и даже от одного человека к другому, они также должны опираться на международные исследования и сотрудничество в этой области.

\section{Introduction}

Intervening in or reversing radicalization processes must be a key element of any sound counterterrorism policy. In the decades following the 11 September 2001 terrorist attacks, the need for deradicalization policies became increasingly obvious in the United States for two reasons. First, enormous U.S. investments in both lives and treasure in 
Iraq, Afghanistan and beyond proved insufficient to destroy the threat of terrorist attacks at home. While terrorist threat to the U.S. homeland decreased and remained contained, AI-Qaeda and ISIS-inspired violence still occurred and heightened popular anxiety both in the United States and worldwide. Second, the vast majority of those terrorist plots and attacks that did occur in the United States in the period since 9/11 had been planned either by U.S. citizens or by legal permanent residents who had arrived in country as children. In other words, most of the terrorists who threatened Americans on American soil had been radicalized within the United States. Neglecting this aspect of the threat would be irresponsible counterterrorism policy.

Efforts to respond to the threat of Al-Qaeda, Daesh, and their affiliates and associates therefore had to include measures to protect U.S. citizens and permanent residents against active recruitment to engage in terrorist violence. Since the ongoing threat these groups pose is at least partially ideological, counter- and deradicalization efforts continue to be the logical response. The threat of homegrown terrorism cannot be addressed without understanding and counteracting the belief systems that move people to violence.

However, all this sounds a lot easier than it is. Before any potential shared framework for the U.S.-Russian cooperation on deradicalization could be devised, the contrasting long historical experiences of each country with respect to terrorism have to be considered.

In Russia, there is a deep history of looking at terrorism as a fundamental threat to the state and national stability, a key element of government legitimacy. This draws from a past in which high profile terrorist attacks by social revolutionaries killed key leaders (most notably Tsar Alexander II in 1881), helping to delegitimize the tsarist empire and usher in years of revolutionary upheaval and regime change that killed millions. Counterterrorism also reflects a history of foreign intervention, an experience that again prioritizes the integrity of the state. According to this view, the state must guard against provocative terrorist attacks that aim to undermine its strength and lead to both domestic instability and outside meddling.

In the United States, terrorism is primarily seen as a threat to private individuals, whose protection is the top priority of the democratic state and the source of its legitimacy. The American perspective is rooted in the late nineteenth century campaign against the anarchists. While they also killed a key U.S. leader (President McKinley in 1901), at that time - and through the twentieth century - the solution to this problem was primarily beefed-up law enforcement. That changed after 9/11 and shifted toward the use of U.S. military force abroad, though nonetheless grounded in a reinterpretation of key legal principles at home. The U.S. Constitution protects and privileges the rights of individuals. U.S. foreign interventions in the wake of the 2001 attacks were justified as a way to protect the American homeland, meaning the lives of individual American citizens.

These two historical foundations inevitably influence each country's priorities and approaches in responding to the threat of individual radicalization. There will be areas 
where the two countries' approaches overlap and areas where they sharply diverge. Furthermore, processes of radicalization and deradicalization are already extremely complex. While many deradicalization programs have emerged throughout the world, their approaches and outcomes vary greatly from country to country. The only viable path forward is to cleave as closely as possible to objective evidence about what works and what does not work and to be certain that we are comparing like with like.

Still, the academic research is embryonic and needs further development. To begin on a firm foundation, we must consider four elementary questions.

\section{What is radicalization?}

The definition of radicalization is contested. ${ }^{1}$ The term has become politicized and often reflects the biases (and funding) of the person defining it. Some even argue that it is completely dependent upon context. The European Commission's Expert Group on Violent Radicalisation, for example, concluded in 2008 that "radicalisation is a contextbound phenomenon par excellence" and defined violent radicalization as "socialization to extremism which manifests itself in terrorism". ${ }^{2}$ In the United States, the term "radicalization" emerged after the 11 September attacks. Prior to 2001, the same notion might have been called "indoctrination", "inculcation", or even "brainwashing" - the word used to describe what the Symbionese Liberation Army did to kidnapped newspaper heiress Patty Hearst in 1974, for example. How the concept is defined makes a great deal of difference in determining both the nature of the process and the individuals likely to be "radicalized".

Most people today use the word "radicalization" to refer only to violent Islamist extremism, especially so-called jihadist terrorism. This is despite the fact that respected, apolitical experts think the concept of radicalization embraces any extreme set of beliefs. Brian Jenkins, one of the most senior and universally esteemed U.S. terrorism experts, defines radicalization as "the process of adopting for oneself or inculcating in others a commitment not only to a system of beliefs, but to their imposition on the rest of society". ${ }^{3}$ His formulation is not limited to religious beliefs but also includes extreme political ideologies if they justify or impel symbolic acts of violence against noncombatant targets. Plus, religious and ethnic identities often overlap. Some longerlived groups have transitioned between political ideologies and religious ones (think the the GIA in Algeria, Hamas in the Palestinian territories or Hezbollah in Lebanon). Confining the word "radicalization" only to a process of "jihadist" religious inculcation risks leaving out many potential terrorist threats.

At its heart, radicalization is the process whereby a person begins to hold extreme views or radical ideas. But there are two key areas of ambiguity. First, what are radical ideas? Can they only emerge from those with whom we disagree? This risks using the term as a kind of ideological litmus test, whether or not an idea is "radical" can be subject to interpretation. There are key sensitivities regarding right-wing domestic extremism in both the United States and Russia, for example, because assessments 
about what represents a right-wing group or a right-wing ideology are politically sensitive. Was Oklahoma City killer Timothy McVeigh "radicalized"? Left-wing and ethno-nationalist terrorism also has a mixed historical legacy, steeped in violence on behalf of some causes with which some people might actually be sympathetic. Were the Marxist-inspired terrorist movements of the twentieth century "radicalized"? Would we label members of "Irgun" (the Jewish organization that was vital to the establishment of the State of Israel) or members of "Umkhonto" (the military wing of the African National Congress in South Africa) "radicalized"? The bottom line is that is it much easier to label something "radical" if the ideas are strange and unfamiliar to the people doing the labeling.

Related is the second area of ambiguity: what is a radicalization process? Some scholars compare it to the complex factors that lead young people to join gangs. There have been outstanding academic studies demonstrating discrimination against specific communities, such as Muslims living in France or Britain, for example. ${ }^{4}$ At the societal level, belonging to a community that is marginalized, economically disadvantaged, victimized, or discriminated against can increase the likelihood of radicalization. Anger at political developments or government policies at home or abroad can play a role. Psychological vulnerabilities may also be relevant, including a sense of personal failure, a yearning for individual agency or adventure, a search for identity, deep empathy for victims, or an overwhelming need to belong to something. But beyond these generalizations, identifying who is or is not likely to be radicalized beforehand is virtually impossible: in the wake of $9 / 11$, well-funded scholars have been trying for years, without success, to build a single coherent "model" of radicalization. And it's not just a question of what people think, but also what they do. So let us turn to the second fundamental question, which is at the nub of the problem.

\section{What moves radicalized people to violence?}

A key focal point in the study of radicalization is the movement from ideas to action. After all, the question of what someone believes does not become critical unless they try to kill on the basis of those beliefs. A vast amount of research, under the burgeoning categories of "counter-radicalization" or "countering violent extremism", ${ }^{5}$ has focused on trying to understand how individuals go from adopting extremist ideas to engaging in violence. This is a vital area of study; but it is often addressed in the aftermath of violent events. Since the goal is to prevent terrorist attacks, that does not achieve the underlying policy purpose. Moreover, before violence occurs, it is devilishly difficult to build scholarly research designs that avoid increasing the sense of marginalization among the communities under examination, thus contributing to the problem of radicalization.

In their research, scholars tend to divide along the thinking/action line. Those who focus on thinking have put together competing models of cognitive radicalization. Out of

this research numerous theoretical models have emerged, from "conveyer belts" 6 and 
"staircases"7 (i. e., linear processes), to "pyramids"8 (winnowing out processes). Each of these studies is trying to tease out stages of individual mental transformation from curiosity to adoption of an extreme ideology, especially violent radical Islamism, which becomes a motivation for action. ${ }^{9}$ Those who engage in these types of approach tend to be psychiatrists, psychologists or sociologists, emphasizing the broad political and social contexts that contribute to terrorist violence.

On the other hand, those who focus on the action side of the equation emphasize how extremists cross over into violence. Their studies build models describing "action pathways" 10 or "behavioral radicalization" for example. ${ }^{11}$ Generally, they examine individuals who have already engaged in violence, develop detailed histories and try to identify the steps that led to that violence. These investigators tend to be lawyers, criminologists or political scientists, usually concentrating upon violent episodes and working backwards.

Neither of these approaches is satisfying when it comes to building effective counterterrorism policy. As with most research on human subjects, cognitive and behavioral explanations are complementary but inadequate. The relationship between human thinking and action is complex. For example, Larossi Abballa videotaped himself in 2011 slaughtering bunnies in the forest of northern France. Should law enforcement officials have known that five years later he would attack a French couple with a knife in the name of the Islamic State and leave them to bleed to death? ${ }^{12}$

There are two other weaknesses with a simple thinking/action research paradigm. Sometimes individuals think without acting, but it is very difficult to examine events that did not occur. Studies rarely use randomized controls when they generalize about sources of radicalization, for example, examining why individuals with dangerous ideas decide not to act - so, thinking without acting. ${ }^{13}$ Especially in liberal democracies, focusing upon someone who has radical thoughts but engages in no violent behavior violates basic protections of the rights of individuals. Should law enforcement agencies become the "thought police"?

Likewise, individuals can act without thinking. Untangling individual motivations can be extremely difficult, especially after an event. Oversimplifying mental processes can lead to erroneous assumptions about complex motivations. These approaches do not explain why individuals who lack any coherent internalized political ideology take action. Even if those individuals cite political extremist groups as the reason they kill, they may be doing so to gain media attention or build an image of strength or respond to mental health problems. In other words, there can be terrorism without radicalization.

This may have been the case with Omar Mateen, who in June 2016 killed 49 people in an Orlando, Florida nightclub in the United States and claimed it was in the name of ISIS. Yet officials have found no prior evidence of logistical connections or even consistent, strong interest in the Islamic State's violent ideology prior to the event. The key warning signs in his case may have been confusion about his own identity and a tendency toward violent behavior - something that describes millions of other young 
people who do not become terrorists. ${ }^{14}$ In any case, unraveling the motivations of that senseless attack has been extremely difficult and is an ongoing puzzle for investigators.

If today's scholars were to transfer this radicalization framework to familiar cases less fraught with contemporary political bias - such as the $19^{\text {th }}$ century Russian social revolutionaries or the mid-20 th century Western antiwar movements - perhaps, they might abandon the effort to create a single predictive "model" of radicalization altogether. It is much too simplistic. These are fundamental challenges that demand greater attention and objective, apolitical research to improve our work.

\section{What does "deradicalization" mean?}

Given the ambiguities and unanswered questions around the concept of radicalization, how do we grapple with processes of deradicalization? There have been numerous programs throughout the world - from Germany and Norway to Saudi Arabia to Minneapolis, Minnesota (USA) - that are designed to work with individuals who have been radicalized by ideologies ranging from neo-Nazism to 'ISIS' hyper-violent extremism. The goal is to prevent them from being recruited or to debrief and reintegrate them into society afterwards. But how do we measure the effectiveness of such programs? If one has radical ideas but does not act upon them, has (s)he been "deradicalized"?

Deradicalization usually means convincing a person not to have extreme views. ${ }^{15}$ This is extremely difficult to do, because it involves changing their thinking. As noted above, it is difficult to assess thinking: sometimes, individuals claim to have changed their views just so they can get out of detention. The best-known example of this was Said al-Shihri, who spent almost six years in the U.S.-run Guantanamo Bay prison and was released in November 2007. He then went through the Saudi deradicalization program and escaped. Shortly thereafter he reappeared as deputy leader of Al-Qaeda in the Arabian peninsula (AQAP) in Yemen and claimed credit for orchestrating the 2008 bombing of the US Embassy in Sana'a. ${ }^{16}$

A more modest approach than deradicalization is "disengagement," or trying to convince individuals not to act illegally, even if they continue to hold radical views. This is easier to do, but may be much less effective, because these individuals can continue to express their ideas and may potentially affect others. In some cases, they may convince others to carry out violence. And those who claim to have "disengaged" must also be closely monitored by law enforcement or intelligence agencies, to ensure that their behavior is legal. This can involve daunting investments of time, attention and resources.

Both disengagement and deradicalization approaches are highly situation dependent and must ultimately be tailored to the individual. They may involve family counseling, job programs, psychological counseling, religious re-education, vocational training, and even organized group sports or art therapy. Sometimes such measures seem to work: excellent deradicalization/disengagement programs have apparently 
reduced the threat of terrorism in Indonesia, Germany (the Hayat program), and Norway, for example. But just as the investments vary by the individual, national programs may need to be tailored to match the exact nature of the threat within a local context.

\section{How do we assess the effectiveness of deradicalization programs?}

Individual programs boast variable rates of success that are difficult to assess through the usual tools of social science. Indicators such as the number of people who have completed a program or recidivism rates for former prisoners, for example, are not that meaningful in the absence of broader political considerations. The value of deradicalization programs also relates to their role in the terrorism-counterterrorism narrative, as well as the implications of having no way out for those who may be early in their attraction to a cause. Good counterterrorism and law enforcement depends upon human intelligence and cooperation with local communities and families, both of whom are served by having alternative pathways for those who resist or turn away. But there are also important political risks for authorities who fear looking "soft" on terrorism and appearing to reward bad behavior.

Recent experience has demonstrated consistent advantages and disadvantages across the range of programs worldwide. Beginning first with the advantages, let us consider the following five.

First, deradicalization and disengagement programs do seem to reduce the threat of terrorism by individuals. Numerous programs offer anecdotal evidence of individuals who claim they wanted to carry out violent acts and then were dissuaded.

Second, they undermine a terrorist campaign's narrative that there is no alternative to violence. This delegitimizes a group's argument that terrorist attacks are the only "solution".

Third, and related, they offer a route out of terrorist participation especially for those who may want to leave a group, but cannot or those who are being actively recruited, have doubts, want trusted advice, and fear their only alternative is prison. They offer a middle way.

Fourth, they are a means for former terrorists to reach those in the process of being radicalized. Disaffected former members are often the most effective and convincing spokespersons against joining a group to begin with.

And finally, when they are concerned with the behavior of specific individuals, these programs give community members greater confidence about cooperating with authorities. This can lead to earlier intervention and may prevent terrorist attacks before they happen. Such cooperation also gives authorities much better insight into the evolving and increasingly sophisticated recruitment techniques being used by terrorist groups, including through social media and the dark net.

However, there are important disadvantages to deradicalization programs as well of which let us again consider five. 
First, they are expensive. Deradicalization and disengagement programs require a wide range of resources and well-constructed plans. Some people see them as rewarding bad behavior (as in Saudi Arabia, for example).

Second, because it is impossible to prove a negative, there is no way to verify for certain that they reduce terrorism. Rates of terrorism may rise or fall, and such changes are suggestive; however, because so many other factors intervene, the direct connection to deradicalization programs cannot be validated.

Third, and related, because deradicalization programs are very difficult to support with objective scientific evidence, they are easy to criticize if something goes wrong. This may be because they raise expectations too high. Recidivism for former prisoners is commonly around $40 \%$ at best, and as high as $70 \%$ in many countries. The Saudi program claimed a recidivism rate of $10-20 \%$, but it had some very high profile recidivists and this deeply undercut their reputation, especially in the U.S. As a result, for good or ill, many deradicalization programs resist providing such statistics at all, further muddying scholarly assessment.

Fourth, deradicalization efforts potentially stigmatize members of certain communities, especially Muslim communities or members of minority groups. For reasons that are unclear, this does not seem to happen when those being treated are members of majority populations. Right-wing disengagement programs - such as neoNazi-focused programs in Germany and Norway - do not seem to adversely affect the broader communities.

Finally, it is very difficult for deradicalization programs to compete with the wide range of radicalized material on social media and the Internet. For these initiatives to work, they must also dominate the cyber spaces where groups present their radicalizing messages. And this is the greatest challenge of all: how to control new means of recruitment and mobilization of violence? When competing with virtual realities, deradicalization programs may offer too little, too late.

\section{Conclusion}

Measures to reverse or interrupt radicalization processes are important to counterterrorism policy, mainly because they undermine the ability of groups to employ the classic terrorist strategy of polarizing marginalized populations. Well-designed programs offer tangible evidence of a middle way, not just for individuals but also for their families and communities. But because the links between groups are increasingly global, these programs cannot be considered in isolation. Although they must be tailored for contexts that vary from state to state and even person-to-person, they must also be supported by internationally linked research and cooperation. Otherwise there is no hope of tackling the increasingly global twenty-first century communications spaces where individuals are being successfully recruited to engage in violence. 


\section{ENDNOTES}

1 Schmid A.P. Radicalisation, De-Radicalisation, Counter-Radicalisation: A Conceptual Discussion and Literature Review. International Centre for Counter-Terrorism (ICCT) Research Paper. - The Hague: ICCT, March 2014. P. 5. URL: https://www.icct.nl/download/file/ICCT-Schmid-RadicalisationDe-Radicalisation-Counter-Radicalisation-March-2013.pdf>.

${ }^{2}$ Radicalisation Processes Leading to Acts of Terrorism. A concise Report prepared by the European Commission's Expert Group on Violent Radicalisation. Submitted to the European Commission on 15 May 2008. P. 7.

3 Jenkins B.M. Outside experts view (Preface) // Homegrown Terrorists in the U.S. and U.K.: An Empirical Examination of the Radicalization Process. Ed. by Daveed Gartenstein-Ross and Laura Grossman. - Washington, D.C.: Center for Terrorism Research, Foundation for Defense of Democracies, 2009. P. 7.

4 Adida C., Laitin D., Valfort M.-A. Muslims in France: identifying a discriminatory equilibrium // Journal of Population Economics. 2014. V. 27. № 4. P. 1039-1086 This is one article that came out of a large multi-year National Science Foundation research project entitled "Muslim Integration into EU Societies: Comparative Perspectives."

5 "Countering Violent Extremism" (CVE) is the term preferred in the United States.

6 Baran Z. Fighting the war of ideas // Foreign Affairs. 2005. V. 84. № 6.

URL: <https://www.foreignaffairs.com/articles/europe/2005-10-01/fighting-war-ideas>.

7 Moghadam F. The staircase to terrorism: a psychological exploration // American Psychologist. 2005. V. 60. № 2. P. 161-169.

8 McCauley C., Moskalenko S. Mechanisms of political radicalization: pathways toward terrorism // Political Violence and Terrorism. 2008. V. 20. № 3. P. 415-433.

9 Neumann P.R. The trouble with radicalization // International Affairs. 2013. V. 89. № 4. P. 874.

10 Borum R. Rethinking radicalization // Journal of Strategic Security. 2011. V. 4. № 4. P. 2.

11 Vidino L. Countering Radicalization in America: Lessons from Europe. U.S. Institute of Peace Special Report, November 2010. - Washington D.C.: U.S. Institute of Peace, 2010.

12 Callimachi R. How do you stop a future terrorist when the only evidence is a thought? // The New York Times. 21 June 2016. URL: <https://www.nytimes.com/2016/06/22/world/europe/franceorlando-isis-terrorism-investigation.html>.

13 A 2013 Minerva grant was awarded by the U.S. Department of Defense for a project entitled "Who Does Not Become a Terrorist". Its results are not yet available.

14 At the time of this writing, Mateen's wife has been arrested for aiding and abetting him in planning the attack. It is not known whether or not she played a role in justifying the attack on the basis of jihadist ideology, if that indeed was its central motivation. Goldman A., Blinder A. F.B.I. arrests wife of killer in Orlando mass shooting // New York Times. 16 January 2017. 
15 This survey will not address the difference between "deradicalization," "counterradicalization" and "antiradicalization". For more on those terms, see Clutterbuck L. Deradicalization programs and Counterterrorism: A Perspective on the Challenges and Benefits. Middle East Institute Brief. 10 June 2015. URL: <http://www.mei.edu/sites/default/files/Clutterbuck.pdf>.

16 Worth R.F. Freed by the U.S., Saudi becomes a Qaeda chief // New York Times, 22 January 2009. 